\title{
Jack Spicer's Impossible Quest for the Holy Grail
}

\author{
Wilhelmus Johannes Lukkenaer \\ Institute for Dutch Literature, Humanities Faculty, Leiden University, Leiden, The Netherlands
}

\section{Email:}

wjlukkenaer@gmail.com

\section{To cite this article:}

Wilhelmus Johannes Lukkenaer. Jack Spicer's Impossible Quest for the Holy Grail. International Journal of Literature and Arts. Vol. 9, No. 4, 2021, pp. 147-154. doi: 10.11648/j.ijla.20210904.11

Received: May 24, 2021; Accepted: June 30, 2021; Published: July 9, 2021

\begin{abstract}
The American poet Jack Spicer (1925-1965) called, in his second lecture for students in Vancouver, his serial poem The Holy Grail (1962), 'fairly simple'. Readers will undoubtedly find it not simple at all. 'Cryptic' would be a better characteristic. But Spicer does not want to be more explicit. Is he concealing something? The poet did not, however, leave us without some clues, two of them being references to authors, namely Jessie Weston and Hans Jonas. The editors of his lectures did give some, but in my view not sufficient, attention to these references. Through this article I intend to correct this shortcoming. Weston's medieval studies, especially those pertaining to Arthurian Literature, contain many elements also present in Spicer's serial poem, thus providing a possibility to examine his poetics more closely. In addition, Hans Jonas's book The Gnostic Religion (1958), subtitled The message of the alien God and the beginnings of Christianity, helps us gain a deeper understanding of Spicer's poem; moreover, it explains his reluctance to write plain language. The knowledge Spicer intends to make known should at the same time remain somehow hidden, because, as an ancient tradition demands: only initiates have a right to know, to obtain access to gnosis.
\end{abstract}

Keywords: Jack Spicer, Poetics, the Holy Grail, Arthurian Literature, Gnosticism, Initiation

\section{Introduction}

Since several years, Jack Spicer's poetry has won a late and new actuality, thanks to new editions of his work [1, 2, 23], and studies from, among others, Daniel Katz [8], Lewis Ellingham and Kevin Killian [6], Lucinda Taylor-Callier [15], Scott Challener [9], R. E. Shoemaker [16], Alan Soldofsky [17], John Granger [19], Daniel O'Donell-Smith [20], Geoffrey Hlibchuck [14], Paul E. Nelson [13], and Robin Blaser [11, 12]. There were translations in Dutch [10, 21, 22]. All these recent editions offer new interpretations, inviting further research and new insights into Spicer's life and poetry. In my article, I interpret Spicer's serial poem The Holy Grail using new insights, based upon an examination of, and comparison with, its key sources of inspiration.

\section{2. 'Knowledge' from an 'Outside'}

The Holy Grail (written in 1962) is an important collection of 'Books', as Jack Spicer (1925-1965) calls the parts of his later 'serial' poems. Each part consists of a series of connected poems - in contrast with his earlier 'standalone' poems, called 'one-night stands' by him, and rejected.

What is this 'Holy Grail'? We are dealing here with a mysterious object, that on earth only exists within the realm of language. It may however exist as well in an 'Outside', as Spicer calls it, but there it is beyond the reach of man.

Now Spicer sets himself the task of opening his mind for messages from that Outside. He adds that he will make his own vocabulary 'as furniture' available to the Outside, so that this for humans inaccessible area can contact our world. His series of grail poems was, he tells us, 'inspired', 'breathed' into him from the Outside, during a meditative writing process lasting months.

The Outside now makes, in its 'inspirational' activities, use of visual material known to literary scholars. I quote from Spicer's second 'Vancouver Lecture': 'If you've read Mallory, it will help you (...) And if you've read Jessie Weston, you might as well leave the room.' ${ }^{1} \mathrm{He}$ would appear to be implying that you would then already know enough, and you will not need his lectures to understand the poems. To which Peter Gizzi, editor of The House that Jack Built, adds a footnote: 'Spicer is probably referring here to Weston's most

\footnotetext{
${ }^{1}[2]$, p. 57.
} 
influential book, From Ritual to Romance (1920) [3], but see also her earlier essay, The Quest of the Holy Grail (1913) [4].

In my view, Spicer's images of the Outside are predominantly derived from the studies of Jessie Weston. Particularly from the above mentioned 'earlier essay'. I will come back to this.

But how do we, as 'ordinary readers', get through to the meaning of these poems?

\section{A Fairly Simple Poem}

Jack Spicer called The Holy Grail in his second 'Vancouver Lecture'2 a fairly simple poem. Even though he adds: 'Except for the damn people in it.' Simple and not simple? It would be simple if you took all those damn people out of the equation. Gawain, Percival, Lancelot, Guinevere, Merlin, Galahad and Arthur are title characters in the seven 'books' of this 'serial' poem. If you were able to take them and all other people away from the series of poems, would there then be something left you could call simple? Or would nothing at all remain? Nothing at all is simple indeed! But we are on our guard. Dual identities might help us further.

Such as this one: in the third poem of The book of Gawain (the first section of Spicer's serial poem The Holy Grail), the grail is both 'the dish in which Christ bled' and 'the chalice of abundance in Irish mythology'. We find these two descriptions of the grail - a Christian and a folkloric one also in the studies of Jessie Weston, whom Spicer as we saw refers to on page 57 of his Lectures.

Weston, however, does not give two, but three interpretations of the medieval tale of the holy grail. ${ }^{3}$ Moreover: she prefers a ritual interpretation over the Christian and folkloric ones. ${ }^{4}$ She traces this back to the preChristian cult of Adonis, who personifies the animating spirit of nature. ${ }^{5}$ Adonis dies and is reborn, just as nature annually dies and is regenerated. Adonis exists both in the over- and underworld, as husband to Aphrodite and Persephone, respectively. The ritual celebrates this alternation.

This ritual would, in the first two centuries of the Christian era, have been included as initiation rite in not only 'heathen' mystery religions, but also, in Christianized form, in early Christian Gnosticism. When the doctrine of the church was streamlined, Gnosticism was admittedly declared to be a heresy, but it would have lived on 'underground' (esoteric, not meant for the general public - so initiates were, just like in for instance the Freemasonry, sworn to strict secrecy) and have left traces in Arthurian Literature - in the twelfth century for example in Chrétien de Troyes and Wolfgang von Eschenbach, in the fifteenth century in Sir Thomas Malory. The sudden total disappearance of Arthurian Literature could also be attributed to the strict ruling Church (even though esoteric initiation rites persist to our day).

We might then be better able to understand more of the

\footnotetext{
${ }^{2}[2]$, p. 57.

${ }^{3}$ [4], Chapter IV, V and VI.

${ }^{4}[4]$, p. 74.

${ }^{5}[4]$, p. 77.
}

'simple' serial poem The Holy Grail, if we are aware of the possibility of references in the poems to pre-Christian or Christian-Gnostic ritual.

\section{An Angel as Messenger}

Spicer refers in his second Lecture to Weston's earlier book - where she by the way mentions Gnosticism twice ${ }^{6}-$ but also, in his third Lecture ${ }^{7}$, to Hans Jonas, an expert on Gnosticism. Peter Gizzi puts the name of Hans Jonas in square brackets here, because 'the name on the tape is unclear', as he explains in footnote 29 on page 146. But he gives us nevertheless the title of Jonas's book and tells us that 'John Granger makes good use of Jonas in his essay on Spicer, "The Idea of the Alien in the Four Dictated Books".' [15]

On the recording Spicer and his interviewers are exchanging views about the Messenger. In a passage about Jacob's wrestling with the angel Spicer says: 'Actually, one of the things I've found up here is that nobody has ever read [Hans Jonas's] books, which do deal with just exactly that kind of thing.' With 'one of the things I discovered', Spicer refers to the fact that Angel in Hebrew means Messenger.

In fact, during the writing of his serial poems Spicer opened himself to messages from another world. That there would be another world - which he called the Outside as stated earlier - and that messages would be able to reach us from there (if we were open to it), is strongly reminiscent of Gnosticism. The book by Hans Jonas on this religion, to which Spicer undoubtedly is referring, was published in 1958.6 [5] The following is a succinct exposition of Jonas's argumentation.

Central to the body of thought of the Gnostic religion is a radical dualism: The Divine is light, the cosmos darkness. The lightless world, our world, is the work not of God but of lower powers, the Archons (rulers). The transcendental God is unknowable for all creatures. For knowledge, Gnosis of Him, supernatural revelation and enlightenment are required, and even then, that knowledge 'can hardly be expressed otherwise than in negative terms. ${ }^{8}$ The universe of the Archons is one big prison, in which we are 'captive'.

Man consists of flesh, soul, and spirit. With his body, but also with his soul, man is part of the lower, material world. Trapped in his earthly soul, however, is the spirit or pneuma, also called spark - a part of the divine substance that has fallen into the dark world: it is the 'lost' Pearl that is locked up in an animal shell: the Archons created man to keep the pneuma trapped therein. In its unredeemed state this pneuma is unaware of its own existence, asleep, or drugged by the poison of the world - ignorant. 'Its awakening and liberation is effected through "knowledge"., The bearer 'of salvation' is 'a messenger from the world of light, who penetrates the barriers of the spheres, outwits the Archons, awakens the

\footnotetext{
${ }^{6}[4]$, p. 104 and 136

[5], p. 142 .

${ }^{8}[5]$, p. $42-43$

${ }^{9}[5]$, p. 45.
} 
spirit from its earthly slumber, and imparts to it the saving knowledge. (...) Equipped with this gnosis, the soul after death travels upwards, leaving behind at each sphere the psychical "vestment" contributed by it: thus the spirit stripped of all foreign accretions reaches the God beyond the world and becomes reunited with the divine substance.'

Jonas then proceeds to explain the psychological and moral state of those equipped with gnosis: 'In this life the pneumatics, as the possessors of gnosis called themselves, are set apart from the great mass of mankind. The immediate illumination not only makes the individual sovereign in the sphere of knowledge (...) but also determines the sphere of action. Generally speaking, the pneumatic morality is determined by hostility toward the world and contempt for all mundane ties. From this principle (...) two contrary conclusions could be drawn [...] the ascetic and the libertine. (...) The pneumatic is (...) free from the yoke of the moral law. To him all things are permitted (...). ${ }^{10}$ In Gnosticism there is no question of sin, only of ignorance. Therein lies the liberating contrast with Christianity - which for that reason eradicated the Gnostics as much as possible for being heretical.

Hans Jonas is of the opinion that faith is the response to the call from beyond that cannot be seen but must be heard'. ${ }^{11}$ Spicer also listens to the signals - the static - from the Outside. The poet is leaning here heavily on the movie Orphée (1950) of the French writer and film director Jean Cocteau, in which Orpheus receives his messages from the other/underworld via the car radio.

Jonas sees the Messenger or Envoy as 'in relation to the world, the Alien Man'. ${ }^{12}$ Likewise, Spicer perceives the envoys of the other world as aliens, 'Martians" ${ }^{\text {, }}$ and with his friend John Ryan spoke Martian on the North Beach of San Francisco, 'just to bug the tourists. ${ }^{14}$

'Sea or waters' - also frequently appearing in Jack Spicer's work - 'is a standing gnostic symbol for the world of matter or of darkness into which the divine has sunk ${ }^{15}$. Spicer uses the waters of the Pacific off California's west coast in his work as symbols for the 'low' material but also for the 'high' divine.

According to Jonas, ${ }^{16}$ 'In the New Testament, especially in St Paul, this transcendent principle in the human soul is called the "spirit" (pneuma).' Paul 'opposes, as did the Greek-writing Gnostics after him, "soul" and "spirit", and "psychic man" and "pneumatic man".' The earthly soul (psyche) as we have already seen, is part of our earthly body, the spirit (pneuma) is, as a divine 'spark', imprisoned in that despicable body.

The Messenger descends to free the pneuma from its imprisonment. 'We can confidently take the King's Son to be

\footnotetext{
${ }^{10}$ [5], p. 46

${ }^{11}[5]$, p. $74-75$.

12 [5], p. $75-76$.

13 [2], p. 24.

14 [2], p. 12

${ }^{15}$ [5], p. 117.

${ }^{16}[5]$, p. 124.
}

the Savior, a definite divine figure, and not just the personification of the human soul in general. Yet this unique position does not prevent him from undergoing in his own person the full force of human destiny, even to the extent that he, the savior himself, has to be saved. ${ }^{17}$ This 'destiny' for Christians means the bloody crucifixion of Jesus, including the stabbing of the lance in His side. But note: in Gnosticism there is no question of sin, only of ignorance. Therefore, for the Gnostics Jesus did not have to play the role of paying with his blood as reconciliation for the Original Sin of Adam and Eve.

\section{The Medieval Story of the Holy Grail}

The question is now to what extent Gnosticism, as supposed component of the medieval grail stories, can elucidate Spicer's grail poems.

The oldest grail story is, according to Weston ${ }^{18}$, probably the work of Bleheris (or Blihis, Bledri, Bledhericus) from Wales:

1. Arthur's wife, Queen Guinevere, is riding with a few of her knights through a forest, where she awaits the return of her husband from a war expedition, when an armed knight comes riding past the tents, without holding back or saluting the Queen. She first sends the knight Kay after him, but he is thrown from his horse, after which Gawain chivalrously asks the unknown man to come back. The stranger hesitates - he gives as his reason that he is on a quest that cannot be delayed. Then he yields. But before they can reach the camp, the knight unleashes a penetrating shriek and falls, mortally wounded by a spear, thrown by an invisible hand. Dying, he asks Gawain to take over his quest.

2. Gawain, burning with shame and indignation (he had promised the knight safe passage), goes on his way. 'He rides through a terrible night of storm and tempest, in the course of which he shelters in a mysterious chapel, where a Black Hand, appearing from behind the altar, extinguishes the light, and hideous voices make lamentation. Gawain's steed, terrified, carries him away, and we are told that but for his valor and worth the knight would have died.' In the morning Gawain 'rides through a land waste and desolate, and at nightfall comes to the seashore. Across a dam, flooded by water, at the end of which 'glimmers a light,' his horse 'carries him to the lighted doorway of a castle.

3. At first Gawain is warmly greeted here as a long wished for visitor, but then, recognized as a stranger, he is disarmed and left alone. Now, in the center of the hall in which he finds himself, Gawain 'sees the body of a gigantic knight on a bier, covered with a crimson silk, a sword on his chest, and lighted candles at head and foot.' A procession, headed by a cross of silver enters, and clergy singing the Vespers of the Dead amid general

\footnotetext{
${ }^{17}$ [5], p. 127.

${ }^{18}$ [4], pp. 31-39
} 
lamentation.'

4. After that, tables are set for a feast, the king of the castle enters, greets Gawain friendly and lets him take a seat next to him. Then follows the mysterious appearance, and the serving by, the rich Grail. (Here Weston refers to her earlier description ${ }^{19}$ of two different Grail-forms: a 'rich', not 'holy', mysterious, automatic, food-providing object, and the dish in which the blood of the wound of Jesus Christ, caused by Longinus' lance, was collected).

5. After the feast Gawain is left alone again. Now he sees a Lance that is stuck straight up in a silver dish, and from the point of this lance blood flows, via an emerald green gutter, to a golden tube and from there out of the hall. A little while later the king comes back in, brings him to the bier, takes up the broken sword and bids Gawain to join the two halves together, in which he doesn't succeed. The king shakes his head and tells him that he cannot fulfill the quest that had brought him here. But Gawain has been so courageous, that every question he asks will be answered. Gawain asks about the Lance and the sword, but when the king tells him weeping who has struck with the sword and who has been struck by it, Gawain falls asleep. The next morning, he finds himself at the seacoast again; the land is no longer infertile because he has asked about the Lance, but if he had asked about the Grail, the land would have been completely restored.

Another manuscript inserts another visit by Gawain to the mysterious castle, in which the king is an old man lying on a couch and where a formal Grail procession is being held, consisting of a young man carrying the bloody Lance, a girl with a silver dish, a bitterly weeping girl carrying the Grail (in this case no automatic food-serving object), and four sergeants with a bier on top of which is a corpse and a broken sword.

In yet another version of the Gawain story the king is old, looks sick, and is encountered in a hall strewn with roses. $\mathrm{He}$ is dressed in white and observes, as the knights enter, two chess playing lads. When the Grail procession enters, Gawain recognizes in the Grail-bearer the girl who had earlier warned him that he, if ever he saw her again in the company of other girls, must ask her what she was doing there. He asks that question and the king jumps up shouting with joy; 'he was dead, but retained a semblance of life till the Quest was achieved.' In the morning he disappears with his knights. Only the Grail-bearing girl and her female companions stay behind. They were the only living beings in this dwelling of the dead.

So, what exactly is the Grail? What does Jessie Weston have to say about this mysterious object? She researched the oldest surviving stories about this 'talisman' and found ${ }^{20}$ in them no less than seven different meanings of the word 'grail'. They are:

\footnotetext{
${ }^{19}$ [4], p. 8.

${ }^{20}[4]$, p. $1-2$
}

1. 'a mysterious and undescribed Food-providing Object, which comes and goes without visible agency'.

2. 'a Stone, endowed with food-and life-giving properties, which also from time to time assumes the rôle of an oracle'.

3. ' $a$ "Holy" Object, the form of which is not indicated, wrought of gold and precious stones, and emitting a brilliant light'.

4. 'a Reliquary'.

5. 'the Dish from which our Lord and His Disciples ate the Paschal Lamb at the Last Supper, or the Cup of that Meal'.

6. 'the Vessel (sometimes that just mentioned, whether Cup or Dish, sometimes one special made for the purpose) in which Joseph of Arimathea received the Blood which flowed from the Wounds of the Redeemer'.

7. 'finally, a mysterious combination of these two latter forms with the Chalice of the Eucharist'.

Five of these seven meanings of the grail we find in Spicer's Holy Grail. And there is, very surprisingly, an additional eighth, as Weston writes about Gawain ${ }^{21}$ :

After he, with other inhabitants of the castle, has partaken of the common feast, and been served by the 'rich' Grail, he is left alone in the hall, and then, and not before, he sees the Vessel in its lower aspect, as a Cup, or Vase, receiving the blood which flows from an upright Lance. Vase and Lance, in this conjunction, are well-known phallic symbols, the Vase, or Cup, representing the female, the Lance, or Spear, the male element, where the blood is the Life.

A little Freudian foray, which Spicer will have enjoyed! And an eighth possible meaning of the Grail-Vessel - in the lower, earthly, poetic sense!

This mysterious object of many meanings is not material (is therefore no part of our dark world). It is, Weston writes: 'as one romance definitely states, being of no material substance whatsoever, "for of wood was it not, nor of any kind of metal nor of stone was it wrought, neither of horn, nor of bone", 22

\section{Jack Spicer's Grail}

Which of Weston's descriptions of the Grail occur in Spicer's Grail cycle? The Grail is sought by knights (not however by the Queen) of King Arthur's Round Table. The knights participate in the quest for the Grail. They also play a part in Spicer's Holy Grail.

We find two opposite forms of the Grail in The book of Gawain: 'the cup of plenty in Irish mythology' (Weston's first meaning) and 'the cup Christ bled into.' (Weston's sixth meaning). These objects are each other's opposite: the Irish meaning stands for poetry (the lower, earthly). This Irish Grail 'fills us up' (is food for earthlings) 'instead of using us as a cup the dead drink from.' (Compare this with the eleventh Book of the Odyssey, The Realm of Ghosts, where

\footnotetext{
${ }^{21}[4]$, p. 90

${ }^{22}[4]$, p. 2.
} 
the dead from Hades are quenched with blood). 'These worlds make the friendliness of human to human seem close as cup to lip, but leaves us "Unfulfilled".'

Compare with the first section of Spicer's poem, The book of Gawain: 'The Grail they said / Is achieved by steady compromise. (...) The prize is there at the bottom of the rainbow - follow the invisible markings processwise / I, Gawain, who am no longer human but a legend followed the markings / Did / More or less what they asked / My name is now a symbol for shame / I, Gawain, who once was a knight of the Grail in a dark forest.'

The Dantesque selva oscura (dark forest), has become a symbol of shame. Gawain's quest did not lead to a healing of the king, because the key question was neither asked nor answered. Gawain got far, but at the crucial moment he lost the required consciousness and was overwhelmed by sleep.

In the second section, The book of Percival, the title character takes on the quest and plays the fool - he is followed by the fool killer, who 'thinks that just before the moment I will find the grail he will catch me.' (Later on in the story, he is Percival's shadow, beating itself against a rock). 'It was not searching the grail or finding it that prompted me / I was playing the fool)' I 'knew that the cup or the dish [Weston's sixth meaning] or the knights I fought didn't have anything to do with it.' Then with 'No visible means of support (...) the Grail hung there with the seagulls circling round it '..." "Fool," they sang in voices more like angels watching / "Fool".'

In the third section, The book of Lancelot, the dish (Weston's sixth meaning) is sufficiently precious for this seeker of the grail. He 'took a chance on this, heard the adulterous sparrows murmuring in the adulterous woods / Willing to pay the price of this with his son or his own body.' (like the Biblical Abraham!) But 'The grail, not there, becomes a light which is not able to be there like a lighthouse or spindrift '...' [Weston's third meaning].'

"Hero Lancelot feared the question "what is the holy grail" which nobody asked him' He should ask this question for 'initiation into the higher Secret of the Mysteries, that of regeneration and spiritual life.' But instead, he 'sings a song to himself' (poetry, of the earthly, lower kind!) 'as he goes out to look for the thing. / The Grail will not be his / Obviously.'

What he did find are Guinevere and Elaine, who he 'fucked' (the queen 'only four times', Elaine 'twenty times at least'). Obviously, his 'Lance' is only interested in the 'Vase' or 'Cup' (Weston's eighth meaning).

The first word in the fourth section, The book of Gwenivere, is 'Lance'. The adulterous wife of King Arthur asks how things stand between her and her lover. She is completely earthy and 'sick of the invisible world and all its efforts to be visible.' She wants them both to 'forget the Grail Castle for a moment', where 'They are saying mass' and 'The dumb old king / Awaits (...) Not Christ, but a substitute for Christ as Christ was a substitute. / You knights go out to tear him from the cross like he was a fairy princess turned into a toad. / The cup that keeps the blood shed, bled into / Is a hoax, a hole.' (Weston's sixth and seventh meaning). 'Grails here, grails there, grails tomorrow / A trick of light. / A trick of light streaming from the cup. (...) The celestial City / Winking and changing like a light in some dark harbor.' (Weston's third meaning). Gwenivere ends with an appeal to her lover: 'Lance, the cup is heavy. Drop the cup!' Then she makes a denigrating remark about 'This teacup Christ bled into,' sighing: 'Christ, and this little teacup / Were always between us.'

In the fifth section, The book of Merlin, 'Grail-searchers im Konzentrationslager' [text in German] / 'A Jew stole the grail the first time / And a jew died into it. / That is the history of Britain.' (Weston's sixth meaning). Merlin 'pretended that he was a radio station and listened to grailmusic all day and all night every day and every night.' (The 'static' messages from the Outside.)

Merlin writes: 'The enemy is in your own country', and remarks that: 'when Gawain and Percival and almost everybody else was stumbling around after phantoms / There was a Grail but he did not know that / Jailed.' Merlin says: 'I am Merlin / imprisoned in a branch of the Grail Castle.' From that vantage point he must prophesy about Britain: 'will there be a Grail or a Bomb which tears the heart out of things? / I say there will be no fruit in Britain for seven years unless something happens.'

In the sixth section, The book of Galahad, it is called 'foolish' to 'contemplate (...) the Grail / from purity (...) as if words or poetry could save you. (...) The grail-searchers were dead (...)'. Galahad 'laughed at the feel of being a hero. / Pure. For as he laughed the flesh fell off him / And the Grail appeared before him like a flashlight.' (Weston's third meaning). Pure, in my opinion, means chaste in this context. Gnostics have no need to be chaste because sin does not exist for them.

The 'Austrailians' hit by Italian bullets on their 'fool's errand' in Greece followed an order from the cup which 'said: "Drink me" so we drank '...' (Befehl ist Befehl (Orders are Orders) this time on the Allied side).' But 'Galahad had a clearer vision. Was an SS officer in that war or a nervous officer (Albanian, say), trying to outline the cup through his glasses. / The Grail lives and hovers / Like bees / Around the camp and hovers / Like bees / Around the camp and their love, their corpses. Honey-makers.' (Weston's sixth meaning). The Grail is 'the cold, bitter cup' of death. Compare: 'Let this cup pass me by'. ${ }^{23}$ Galahad was as only quester 'allowed to find it.' But 'in such a way that the dead stayed dead and the waste land stayed a waste land. ${ }^{24}$

In a 'Transformation' Galahad becomes 'not a fool of the grail like the others were but an arrow, ground fog that rose up and down marshes, loosing whatever soul he had in the shadows / Tears of ivy.' As the only mortal (sole dier and soldier) 'in a land of those who had to stay alive'. But that was a 'Cheat of dream (...) And the land was the same / The

\footnotetext{
${ }^{23}$ Matthew 26: 39.

${ }^{24}$ Both Spicer and T. S. Eliot refer to Weston's book From ritual to romance. Eliot in the Notes to his poem The Waste Land (1926), [7], p. 76.
} 
story the same / No hand / Creeping out of the shadows.'

In the thoughts of Galahad, 'The grail was merely a cannibal pot / Where some were served and some were not (...) was mainly the upper air / Where men don't fuck and women don't stare (...) alive as a starling at dawn '...' a red balloon / It carries him with it up past the moon (...) Blood in the stars and food on the ground, the only connection that was ever found '...".

'The Grail is (...) Not lost but misplaced.' The land is fertile once again, and 'Man / Has finally no place to go but upward '...'.'

In the seventh section, The Book of the Death of Arthur, which closes the cycle, we find quite a few details that can be related to both Jessie Weston and Hans Jonas, therefore both with the medieval Arthur-romances and with Gnosticism pre- and early-Christian. We list these details as they appear in the poems of this section:

1. 'The door not opened by a human hand.' This of course refers to the invisible hand from the mysterious 'other world' of the Arthurian stories. And therefore, to the inaccessible Divine region/Godly area of Gnosticism.

2. 'Marilyn Monroe being attacked by a bottle of sleeping pills (...) Lance me, she said/ Lance her, I did.' 'Lance' stands for fucking (Weston's eighth meaning). 'The sword in the rock is like a children's story told by my mother' (Weston's second meaning). 'He took her life.' Spicer makes Monroe into a new Ophelia: 'And when she floated in on the barge or joined the nunnery'. ${ }^{25}$ Her death was, according to king Arthur, the 'shame' of the killer who cuckolded him (Lancelot), not his.

3. Three 'knights with difficult tasks '...' are transported to three different places. When they awake the magic ship has vanished (...)'. They awake, so they were sleeping again that sleep that makes their quest unsuccessful.

4. 'A meal for us there lasts a century'. Compare Psalm 90:4: 'For a thousand years in thy sight are but as yesterday when it is past', and Peter 2:3:8: 'With the Lord a day is like a thousand years, and a thousand years like a day. ' Time as opposed to eternity.

5. Arthur, he says, has 'forgotten why the grail was important / Why somebody wants to reach it like a window you throw open. Thrown open / What would it mean?' (A window to the other world, the Outside? Even the king has forgotten what it meant).

6. The blackness (two times); 'It is there like the sun (...) blackness alive with itself '...' a monstrous anti-grail (...) It is a simple hole running from one thing to another.'

7. We live on earth in time: 'Time future '...' Time present. Time past'. Arthur is 'king and future king / A noise in the head of the prince. Something in God-language / In spite of all this horseshit, this uncomfortable music.' In the present we have only static in our head - messages in the language of the Gods - from the prince (the Messenger).

25 Compare Hamlet to Ophelia: 'Get thee to a nunnery', where Hamlet is not referring his beloved to a (chaste) cloister but to a brothel, Elizabethan slang for a house of pleasure.

\section{Spicer in Search of the Grail, of Gnosis}

Spicer's Book of Gawain begins with the words 'Tony / To be casual and have the wish to heal. / Gawain, I think / Had that when he saw the sick king. But he 'is no ghostman', so he cannot answer 'a riddle maybe only ghostmen could answer.'

The medieval Grail stories are about sickness and healing. The sickness of the King in the Grail castle consists of infertility. This illness inflicts not only him, but all of nature. As we have seen, the cycle of nature is the origin of Gnostic rituals. The land lies 'in waste' and can only be revived when the mystery of the royal illness has been solved. This is not 'easy'. To do it, knowledge (Gnosis) is required - a question must be asked and answered.

Gawain's quest does not lead to the king being healed, because the necessary question is asked nor answered. Gawain goes far, but not far enough. He falls asleep, and the king remains in a state of apparent death or apparent life, till (sometime in the future) the quest will be crowned with success.

Does another world exist, where we can find healing for our mortality? A grail world that fulfills us, while poetry only quenches the dead?

The question that lies now before us: what does Jack Spicer have in common with Gnosticism in general and with Jonas's book on the subject in particular? And where did his interest in it originate? At the age of sixteen, he met Aldous Huxley. His biographers ${ }^{26}$ write: 'studying Huxley's texts on the expansion of consciousness, and learning about Buddhism and Hindu practices through Huxley's popular explications, propelled Jack into a serious study of comparative religion once he went to college.'

Language made it possible to communicate with your contemporaries. That is what Spicer did, but in fact he did not want to at all! He did not even want to publish. Spicer wanted to leave his loathsome body. He succeeded in the end by destroying his liver with alcohol.

What would he have wanted, apart from earthly love? What kept him busy his entire life? Certainly not just the disruption of his friendships with others and the disruption of relationships between others. In my view, it was Gnosticism - in fact, a special form of this Gnosticism - the life-long anxiously concealed source of his inspiration.

$\mathrm{He}$ was after all, from a tender age, intrigued by the unbridgeable contradiction between our dark earthly existence, the lower world (in which we are imprisoned, with both body and soul) and the higher sphere of the Divine. He fantasized in his work about breaking through a barrier - the barrier of our language, the iron wall between low and high - through a Messenger, sent by the Divine King, and about the salvation of the mortal from the Realm of Language.

In my opinion, Spicer, in his kaleidoscopic poems of The Holy Grail and in the Lectures delivered shortly before his

\footnotetext{
${ }^{26}$ [6], p. 7.
} 
death, granted us a look into what occupied him ever since he was a boy.

In his Lectures he left behind two 'keys': references to Jonas and Weston respectively, both of whom infer an ancient initiation ritual that offered initiates the gnosis, required for the salvation of their pneuma. Guilt free, perhaps even amoral, libertine.

\section{A Struggle with Language}

To circumvent the taboo of revealing enlightened, esoteric knowledge, Spicer did choose to keep the writing-method of his Grail poems - his poetics - for the ordinary reader as dark as possible. He strews, you could say, riddles through his poems. And yet, at the end of the second Lecture, ${ }^{27}$ he describes something like a preparation for the ritual: meditations based on the 'right methods' of Saint Ignatius (though he warns, that this Jesuit makes his cell so empty that there is no possibility for anything from the Outside to get in!). Nevertheless: 'I think that's the first thing for the poet, yes (...) to empty themselves out of themselves first and start receiving, and then go on from there'.

But in his third Lecture Spicer calls this recommended emptying process impossible. His answer to the question: 'Your mind is a blank?' is: 'No, it isn't, unfortunately. It's trying to be a blank. (...) The point is that you can't really make your mind a blank. You cannot really get to receiving God, which Saint Ignatius wanted, or receiving poems, or doing anything. You can't. It's impossible. ${ }^{28}$

Here we are reminded of the last words Spicer spoke on his deathbed: 'My vocabulary did this to me.' (Spicer was a linguist - he knew what he was talking about). Then the question we must ask is: what is it that his vocabulary has done to him?

Language is our earthly prison. We people - and a fortiori poets - cannot break through that barrier. We are imprisoned lifelong behind it. The Kantian Ding an sich is inaccessible.

Spicer's poetry-writing can be seen as a fight against language. Words were bothersome furniture, an individual or collective human possession that prevented a clear view of the presumed and sought-after superhuman world, the Outside. And yet you could not - as a poet in particular and as a human being in general - do without language.

The mystic gropes in the 'void', whereas the initiate - poet or not - is aware of the impossibility of his endeavor. What ultimately remains, is death.

\section{Conclusion}

This article exemplifies a different, more probing reading of Spicer's serial poem The Holy Grail, in the light of sources which have remained implicit in Spicer's extensive body of work. Spicer's complex, multilayered, even cryptic work, may in my opinion benefit from approaches that take

\footnotetext{
${ }^{27}$ [2], p. 90.

${ }^{28}$ [2], p. 116.
}

into account dissimilar sources of inspiration. In this way, new insights might be gained. An exploration, for instance, of the symbolic meaning that Tarot Cards have contributed to his poetry, has been proposed long ago [18], but to my knowledge never been executed.

\section{Acknowledgements}

I am greatly indebted to my friends Jacques Schmitz and Kees Snoek. With the former, Dutch poet and journalist in Berlin, I worked together on playful publications - in German and Dutch - regarding Jack Spicer's life and work $[21,22]$; without the enthusiastic help from Sorbonneprofessor Snoek this article would never have been achieved.

\section{References}

[1] Spicer, Jack: My vocabulary did this to me. The collected poetry of Jack Spicer, edited by Peter Gizzi and Kevin Killian (Middletown, CT: Wesleyan University Press, 2008).

[2] Spicer. Jack: The House that Jack Built. The collected Lectures of Jack Spicer, edited by Peter Gizzi ((Middletown, CT: Wesleyan University Press, 1998).

[3] Weston, Jessie L.: From Ritual tot Romance/ The King Arthur Legends, (1920) (Free on the Internet - See the text in Project Gutenberg or reprinted in for instance ISBN-13: 9781534821361).

[4] Weston, Jessie L.: The Quest of the Holy Grail (1913) (photostatic reprint Barnes \& Noble, New York 1964.

[5] Jonas, Hans: The Gnostic Religion - The Message of the Alien God \& the Beginnings of Christianity (Beacon Press, Boston, MA 1958, reprinted 2001.

[6] Ellingham, Lewis and Killian, Kevin: Poet be like God - Jack Spicer and the San Francisco Renaissance (Hanover and London: University Press of New England, 1998).

[7] Eliot, T. S.: The Complete Poems and Plays, edited by Valerie Eliot (London: Guild Publishing, 1987).

[8] Katz, Daniel: The Poetry of Jack Spicer (Edinburgh: Edinburgh University Press, 2013).

[9] Challener, Scott: Addressing "Alien Worlds": Publics and Persons in the Poetry of Jack Spicer (Madison: University of Wisconsin Press, Contemporary Literature, 2017, Vol. 58 (4), pp. 492-525).

[10] Spicer, Jack: Citroenen, gedichten en zeewier ['Lemons, poems and seaweed'], translated, with an afterword by Jan H. Mysjkin (Bleiswijk: Uitgeverij Vleugels, 2018).

[11] Blaser, Robin: The Collected Books of Jack Spicer (Santa Rosa: Black Sparrow Press, 1999).

[12] Blaser, Robin: The Fire: Collected Essays (Berkeley: University of California Press, 2006).

[13] Nelson, Paul E.: Notes on The Practice of Outside: Robin Blaser's Divine Real (Notes on The Practice of Outside: Robin Blaser's Divine Real | Paul E Nelson, 2013, collected June 14, 2021). 
[14] Hlibchuck, Geoffrey: From Typology to Topology: On Jack Spicer (Madison: University of Wisconsin Press, Contemporary literature, 2010-07-01, Vol. 51 (2), pp. 310-340).

[15] Taylor-Callier, Lucinda: Dictation, the Outside and the Dead: Elements for a Necropolis, Master of Arts by Research (MARes) thesis, University of Kent, 2017.

[16] Shoemaker, Robert Eric: After After Lorca: Anamnesis and Magic between Jack Spicer and Federico García Lorca, Print \& Online, 2019.

[17] Soldofsky, Alan: Those to Whom Interesting Things Happen: William Carlos Williams, Kenneth Rexroth, Lew Welch and Joanne Kyger, and the Genome of San Francisco Renaissance Poetry, William Carlos Williams Review, Volume 35, Number 2, 2018.

[18] Spicer, Jack, Blaser, Robin and Granger, John: A Plan for a Book on Tarot, boundary 2, Vol. 6, No. 1, Jack Spicer. (Duke University Press 1977), pp. 24-29.

[19] Granger, John: The Idea of the alien in Jack Spicer's dictated books, Thesis, Department of English, Simon Fraser University 1982.

[20] O'Donell-Smith, Daniel: Vox ex machina: towards a digital poetics of the disembodied voice, Doctoral thesis, Birkbeck, University of London, 2017.

[21] Lukkenaer, Pim and Schmitz, Jacques: Jack Spicer's De Oceaan, a lost book, Berlin/Rotterdam 2018.

[22] Schmitz, Jacques: Jack Spicer's Holy Grail, translated, Berlin/Rotterdam 2018.

[23] Katz, Daniel: Be Brave To Things. The uncollected Poetry and Plays of Jack Spicer, Wesleyan University Press, to be published December 2021.

\section{Biography}

Dr Wilhelmus Johannes Lukkenaer, Senior Lecturer (19731996) at Leiden University, obtained his PhD in 1989 on a thesis about the novels of Dutch author Louis Couperus (1863-1923) which are set in the Antique World. Besides his thesis and various articles about Louis Couperus, he has studied the poetics of Dutch poets such as Leopold, Van Ostaijen and Nijhoff, and is publishing to this day new translations of German, French, English and Swedish texts. 